\title{
兩周傳世文獻所見之醫療巫術考察
}

中國人民大學 歷史學院 歷史系 ${ }^{1} \cdot$ 慶熙大學校 韓醫科大學 原典學敎室 ${ }^{2}$

趙容俊 $^{1} \cdot$ 白裕相 $^{2}{ }^{*}$

\section{A Research on the Shamanistic Medical Activities of the Traditional Chinese Classics in the Zhou Dynasty}

\author{
Cho Yong-jun ${ }^{1} \cdot$ Baik You-sang ${ }^{2}$ * \\ ${ }^{1}$ Assistant Professor, School of History, Renmin University of China
}

${ }^{2}$ Dept. of Korean Medical Classis, College of Korean Medicine, Kyung Hee University

Objective : The main idea of this article is to investigate the shamanistic medical activities through the traditional Chinese classics in the Zhou Dynasty. The ancient shaman played a bridge role between human beings and supernatural things like ghosts. Even though he didn't have the super power, the ancients believed that he could take care of all kinds of illness. Therefore, it can be said that the medicine of the Zhou Dynasty was still under the shamanism although it had already started to be specialized and professionalized.

Method : This article is going to look into the detailed aspects of the shamanistic medical activities, for example, divination of illness, Zhuyou(祝由), shamanistic preventive medicine, and so on, through the traditional Chinese classics of Zhou Dynasty.

Result : The medical knowledge of that time stayed in the early stage, so it was simple and raw. Also it had scientific and unscientific characters in itself at the same time. That's why it could be included in the shamanism. And about the shamanistic medical activities seen on underground written attestations, they will be offered through another article of mine, entitled A Research of Shamanistic Medical Activities on Underground Written Attestations in the Zhou Dynasty(兩周出土文獻所見之醫療巫術考察), which is being written now.

Conclusion : From beginning of the Eastern Zhou period, the medicine gradually got to be specialized. And then specialized medical treatments and shamanistic medical activities began to be divided as the different two occupations. However, it is an unchangeable truth that the ancient shaman played an important role in the Chinese traditional medicine. Therefore, it can be said that he was in the very special position in the Chinese traditional medicine.

Key Words : Zhou Dynasty, Traditional Chinese classics, Shamanistic medical activities, Divination of illness, Zhuyou(祝由), Shamanistic preventive medicine 


\section{I . 序 論}

早在原始時期, 人類爲求得生存與種族的繁殖, 賏 對各種危害與影響人類生息健康的疾病的防治，則不斷 進行不解的探索。因此, 對於常見的外傷病症, 古人已 有若干治療的知識。

於考古資料中多有揭示，至於夏商周時代，病症、 病因識別已達相當水準1), 且醫療病患的方法與衛生保 健上的社會成俗, 一方面伴隨無數次成功或失敗的經驗 之積累, 在一定程度上標誌當時社會生活的文明發展狀 態, 與此同時, 又爲後世中國醫學體系的建立與完善, 則芫立其基礎2）。

即使如此, 由於原始社會生活條件艱苦, 食物低劣 粗糙，且衛生條件極差，故對人體組織產生的慢性破壞 作用, 確極嚴重。尤其, 在鬼神概念充斥時的許多遠古 民族，對於不易得見之疾病的致因，則直接歸諸自然界 神祇的降災或鬼在作崇。

因此, 古人爲消病除疫, 乃通常探取各種手段安拱 鬼魂, 或以祭祀討好之, 或以虔悔而消除鬼魂的不滿, 或表示屈服以取悅之, 或用某種儀式驅趕疫鬼。此時藉 助於能溝通人鬼間的媒介, 即巫者的力量而完成其 事3)。

古代巫醫不分, 由於人類將疾病致因視爲鬼魂作 用, 故以巫者充當人鬼間的中介人角色, 則寄希望於巫 術行醫、安撫死神而達於消除疾病的目的4)。因此, 於 舉行治病巫術儀式時, 巫者乃往往使出自己全部解數, 進行充分的表演, 以完成此醫療巫術。正因基於此觀

* 교신저자 : 白裕相, 慶熙大學校 韓醫科大學 原典學敎室 E-mail : baikys@khu.ac.kr Tel : 02) 961-0326 접수일(2013년 10월24일), 수정일(2013년 11월14일), 게재확정일(2013년 11월15일).

1）對於古人的病症、病因識別水本的記述，如在《韓非子·五蛽 》中，便有其記載，其云：“ [上古之世，]民食果荿蜯(蚌) 蛤, 腥臊惡臭而傷害腹胃, 民多疾病。”梁啟雄. 《韓子淺解 》(下冊)第四十九篇《五蛽》. 中華書局. 1960. p.465.

2）詳見拙著. 殷商甲骨卜辭所見之巫術·先秦巫術的傳統及對後世 的影響(增訂本). 中華書局. 2011. pp.322-325. 亦可參見宋 鎮豪. 夏商社會生活史. 人生俗尚與病患醫療(增訂本、下冊). 中國社會科學出版社. 2005. p.711.

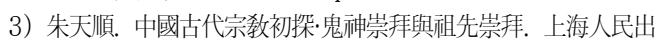
版社. 1982. pp.181-188.

4）宋鎮豪. 夏商社會生活史.人生俗尚與病患醫療(增訂本、下冊). pp.743-756.
念，醫與巫，醫療與巫術密切結合，並且藥物心理與巫 術心理亦取得自然的結合，故求藥及求巫者之事，皆統 一於醫療活動之中5)。

其後進入人文思想萌芽且發展中的周代6), 古人逐漸 脫離此種依賴巫者之迷信觀念7)，則以針、尒以及藥物 爲之 ${ }^{8)}$, 而產生後世專業醫療之術及名醫, 如當時著名 的專門醫生俞跗、醫緩、醫和、扁鵲(即秦越人)9)、文

5）對於求藥與巫術相結合以治病的情形，許進雄在《中國古代社 會》一書中，曾提及三者之關係，其云：“在古代，巫最具實 用的能力是替人治病。……這是因爲巫在行巫術時, 要使自己 精神達到恍惚、狂頡的狀態，才能使自己生幻覺而與鬼神對 話。那種境界很難只由唱歌、跳舞得到，還要借助藥力。有時 病人也要讓他服藥進入恍惚的狀況才能施術。巫對於疾病的反 應和治療的經驗遠較他人豐富, 對某些藥物與病症的關係遞有 發現，很自然由之逐漸發展成爲善用藥物治療的醫生。故傳說 早期的名醫都具有巫的身分，《說文解字》說：“古者巫彭初 爲醫。”許進雄. 中國古代社會 -- 文字與人類學的透視(修訂 本)。臺灣商務印書館. 1995. p.506.

6）有關周代人文思想發展的情形，可參閱拙著. 殷商甲骨卜辭所 見之巫術·先秦巫術的傳統及對後世的影響(賭訂本). pp.284-293.

7）由於周代人文思想的萌芽與發展，不惟自周、秦以降巫者的政 治地位迅速降低，與此同時，擔任巫術性的活動，除巫者之 外，亦有祝、史、卜、宗、樂工等，分擔営之。陳熾涁，左傳 中巫術之研究. 政治大學中文所博士論文. 1989. p.94 133 . 因此，於本文敘述中，除專門從事醫術的醫者之外，凡從事巫 術性醫療活動的人物, 則通稱爲“巫者”。

8）於周代時期，有關以針、众、藥物治病的內容，於《春秋左 傳·成公十年》篇中，便有其記載，其云：“疾不可営也，在肓 之上, 膏之下, 攻之不可, 達之不及, 藥不至焉。不可爲 也。”(淸)阮元校刻。《十三經注疏(附校勘記)》(下冊)《春秋 左傳》卷第二十六《成公十年》。 中華書局. 1980. p.1906. 此外, 《禮記·曲禮下》亦有其記載, 其云: “君有疾, 飲藥, 臣先嘗之。親有疾，飲藥，子先嘗之。醫不三世，不服其 藥。”(淸)阮元校刻。《十三經注疏(附校勘記)》(上冊)《禮記 》卷第五《曲禮下》. p.1268. 不寧唯是, 赤可參見《史記·扁 鵲倉公列傳》的記載，則扁鵲在診齊桓侯之疾時，曾提及針、 炎療法，其云：“扁鵲曰：“疾之居腠理也，湯慰之所及也。在 血脈，鍼石之所及也。其在腸胃，酒醪之所及也。其在骨髓， 雖司命無柰 (奈) 之何。”(漢)司馬遷撰，(宋)裴馹集解，(唐) 司馬貞索隱，(唐)張守節正義. 《史記》(第九冊)卷第一百五《 扁鵲倉公列傳》. 中華書局. 1959. p.2793.

9）對於扁鵲的姓名，司馬遷則稱爲秦越人，如《史記·扁鵲倉公 列傳》便有其記載，其云：“扁鵲者，勃海郡鄭(鄚)人也，姓 秦氏, 名越人。”(漢)司馬遷撰，(宋)裴駰集解，（唐)司馬貞索 隱, (唐)張守節正義. 《史記》(第九冊)卷第一百五《扁鵲倉公 列傳》. pp.2785-2786. 即使如此, 若綜合各種文獻所見的 扁鵲故事, 便知扁鵲的生存時間, 已超越四百年左右。因此, (日)山田慶兒認編，此扁鵲故事，乃爲一種投影理想醫者的傳 說。其云：“ 第一個作業假說］扁鹊傳說不僅是遊方醫的傳 說，而且也是被理想化了的醫師的傳說。某時代之醫師的理想 
摰等。即使如此, 周代的醫療知識, 仍然處於中國醫學 的萌芽狀態, 古樸幼稚, 科學與謬誤參半, 與巫敉信仰 交織一繋10)。

儘管如此, 此時的巫醫, 已開拓壯大醫學的先 河11)。因此, 巫醫於中國醫學上, 則佔有重要的地 位 12$)$

\section{II. 本論：兩周時期的醫療巫術}

\section{1. 巫醫之稱}

若視文獻方面的記載，於中國古代，“巫”可稱之爲 “醫”或“毉”13)，且巫醫不分而屢見醫與巫的連用詞(複 詞)，即“巫醫”之稱。尤其，其中由“毉”字的字形，則 可見治病之事乃爲古代巫者職事之一。

像，作爲在創造其像之人眼中視爲最新、受到最高訴價之技術 與理論的完整體現者，而被刻劃(畫)。……關於扁鹊傳說的我 的第二個作業假說，可以表現如下。即，在今日所傳的扁鹊傳 說中，具有其記述者之時代的醫學狀沉與人們對醫學之願望的 强烈投影。”(日)山田慶兒著, 廖育群, 李建民編礋. 中國古代 醫學的形成. 扁鹊傳說. 東大圖書公司. 2003. p.369.

10）本文在定義上將巫敉信仰與佛、道、基督敉等的敉團宗教不

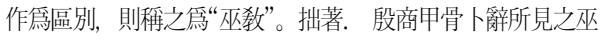
術·巫義研究(㙫訂本). pp.23-58.

11）對於中國㡠學由巫術而發展的見解，陳邦賢在《中國醫學史· 上古的醫學》中會提及, 其云: “中國醫學的演進, 始而 巫, 繼而巫和醫混合, 再進而巫和醫分立。以巫術治病, 爲 世界各民族在文化低級時代的普徧現象, 古書上關於這種紀 載很多。……上諸說都是巫與醫混合時代, 先是用祈暷咒 詛來醫治疾病, 後來人類的知諳漸漸進步了, 知道生病完全 依賴祈禱咒詛是無效的, 於是巫漸渐達到醫乃至藥的地位 了。”陳邦賢. 中國醫學史. 商務印書館. 1954. pp.7-10. 不寧唯是, 馬伯英的《中國醫學文化史.醫學啟源》赤云 : “巫術醫學是中國醫學發展的一個相當漫長而重要的階段。 在醫學起源過程中, 它是第一次形成的一個有結構、成體系 的醫學形式, 具有催生或抽象化理論的基碟作用的階段。與 醫學最初起源關倸最多的是原始思維的形成和發展。原始思 維產生的第一個有價值的理論和實踐成果, 恰恰是巫術醫 學。在這個意義上，人們打出“醫源於巫”的旗號是無可厚非 的。”馬伯英．中國醫學文化史.. 上海人民出版社， 1994. p.186.

12）詳見拙著. 殷商甲骨卜辭所見之巫術·先秦巫術的傳統及對後 世的影響(侁訂本). pp.322-325.

13）有關“巫”可稱之爲“醫”或“嫛”的文獻記載, 如在《廣雅, 釋詁 四·靈子》中, 王念孫疏登於下, 其云 : “醫, 郎巫也。巫與 醫皆所以除疾, 故醫字或從巫作毉。《管子.權修》篇云：

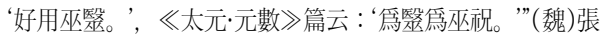
揖, (淸)王念棌疏登。《廣雅疏登》爸第四下《䆁詁》. 香港 中文大學出版社. 1978. p.463.
若視連用“巫醫”之稱的先秦文獻，如《論語·子路》 便有其記錄，其云14）：

子曰: “南人有言曰: “人而無恆, 不可以作巫醫。” 善夫!”

又《管子・權脩》篇亦有其記載, 其云15）：

上恃龜筮, 好用巫毉, 則鬼神驟崇(崇)。故功之不 立, 名之不章。

《逸周書·大聚》亦云16)：

［周公曰：］“卿(鄉)立巫醫，具百藥以備疾災，畜 五味以備百草。”

又《墨子·迎敵祠》亦云 17$)$ :

舉巫醫、卜有所，長具藥，宮 [養] 之，善爲舍。

《呂氏春秋·季春紀》亦云 $18 ）$ :

今世上卜筮禧祠, 故疾病愈來。……上湯止沸, 沸愈不止，去其火則止矣。故巫醫毒藥，逐除治之，故 古之人賤之也，爲其末也。

據上引幾文可以得知，於浩如洷海的先秦古籍文獻 中, 醫與巫的連用詞(複詞), 即“巫醫”之稱, 則屢見不 鮮19)。

14）(清) 阮元校刻。《十三經注疏(附校勘記)》(下冊)《論語》爸 第十三《子路》. p. 2508 . 无其, 對於此文中的“巫醫”, 近 人楊伯峻譯注云：“巫醫是一詞, 不應分爲卜筮的巫和治病

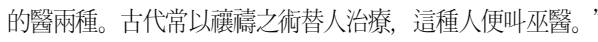
楊伯峻. 論語譯注·子路. 中華書局. 1958. pp.148-149.

15）上海古籍出版社編、《四部精要·子部》《管子》谷第一《權 脩》. 上海古籍出版社. 1982. p.276.

16）黄懷信，张禁鎔，田旭東撰. 《逸周書录校集注(修訂本)》 (上冊)卷四《大聚》. 上海古籍出版社. 2007. p.399.

17）(清)孫詥讓撰, 棌啟治點校.《墨子閒詁》(下冊)第十五《 迎敵祠》. 中華書局. 2001. p.574.

18）上海古籍出版社編．《四部精要·子部》《吕氏春秋》替第三 《季春紀二二日盡數》. p.560. 
不寧唯是，《山海經·大荒西經》亦云20：

有靈山，巫咸、巫即、巫盼、巫彭、巫姑、巫真、 巫禮、巫抵、巫謝、巫羅十巫，從此升降，百藥爱在。

亦在《山海經·海內西經》云21）：

開明東有巫彭、巫抵、巫陽、巫履、巫凡、巫相，

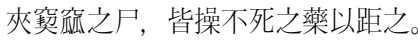

郭璞對此六巫，注云：“皆神醫也。”22)，而又引《 世本》日: “《世本》日 : “巫彭作醫。”23)。

又如《呂氏春秋·審分覽》亦云 24$)$ ：

巫彭作醫，巫咸作筮。

據此幾文不難得知，於先秦的古籍文獻中，則屢見 不鮮治病之事與古代巫者相關的記載。

再視《說文解字·醫》下的記載，其云：“豎，治病 工也。从殹, 从西。殹, 惡姿也, 醫之性然。得酒而 使，故从西。王育說。一日：“殹，病聲。”酒，所寻 (以)治病也。《周禮》有醫酒。古者, 巫彭初作醫

19）除此先秦古籍文獻的記載之外，於後世的文獻之中，亦屢見 不鮮“巫醫”的連稱，如《說苑修文》便有其記載，其云： “古者有畄(災)者謂之庽。君一時素服, 使有司弗死問疾, 憂以巫醫。匍嗃以救之，晹䉼以方之。”(漢)劉向撰，向宗魯 校登. 《說苑校登》卷第十九《修文》。 中華書局. 1987. p.495. 此外, 韓恿的《韓昌黎集》中, 《師說》篇亦有其 記載，其云：“巫醫、樂師、百工之人, 不耽相師。……巫 醫、樂師、百工之人, 君子不齒, 今其智乃反不能及, 其可 怪也貼! ”(唐)韓愈.《韓昌黎集》卷第一《賦: 雜著師說》。 河洛圖書出版社. 1975. pp.24-25.

20）見(晉)郭䧤注。《山海經》第十六《大荒西經》, 載於《文 浯閣四庫全書》第一 $\mathrm{O}$ 四二冊《子部三四入.小說家類》. 臺 灣商務印書館. 1983-1986. p.75.

21）(至) 郭堘注. 《山海經》替第十一《海內西經》. p.65.

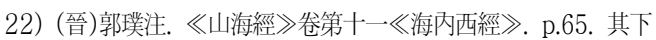
袁珂校注云 : ‘然細按之, 四寧日：‘皆神巫也。’此諸巫無非 神之臂佐，其職任爲上下於天、宣達神旨人情，至於采藥療 死, 特其餘技耳。”袁珂校注。《山海經校注: 山海經海經新 釋》卷第六《海內西經》。 上海古籍出版社. 1980. pp.301-302.

23）(晉)郭堘注. 《山海經》卷第十一《海队西經》. p.65.

24）王利器.《吕氏春秋注疏》(第三冊)然第十七《審分覽·四日 勿躬》. 巴蜀書社. 2002. pp.2004-2011.
。25）此文亦敘述，古時巫醫不分，故治病之事乃爲 古代巫者主要職事之一。

由此觀之，此種常見“醫巫”或“巫醫”之稱呼，以及 “醫”字亦可寫成“㗨”字等的現象，則登明巫與醫有密切 的關係26)。

\section{2. 占卜問病}

於兩周時期的中國古籍文獻中，巫者從事占卜問病 之例, 則屢見不鮮, 如《春秋左傳·文公十八年》便有 其記載，其云27）：

春，齊候戒師期，而有疾。醫日：“不及秋，將 死。”公聞之，上，日：“尚無及期！”惠伯令龜。卜楚 E(丘)占之，日：“齊侯不及期，非疾也。君亦不聞。 令龜有各。”二月丁丑，公薨。

\section{又《春秋左傳·襄公十年》亦云28：}

宋公享晉侯于楚E(丘), 請以《桑林》。荀罃辭。 荀優、士勾曰：“諸侯宋、魯，於是觀禮。魯有楴樂， 賓祭用之。宋以桑林享君，不赤可乎? ”舞，師題以権 夏。晉侯懼而退，入于房。去旌，卒享而還。及著雍， 疾。卜，桑林見。

此文敘述晉侯因觀宋國桑林之舞，驚哧而致疾，後 以龜卜疾病，則兆象顯示爲桑林之神作崇。

不寧唯是, 《春秋左傳·昭公元年》亦有其記載, 其 云29）：

25）(清)段玉裁注。《說文解字注》第十四篇注下《醫》. 藝文印 書館. 1994. p.65.

26）周策縱，古巫醫與“六詩”考 - - 中國浪漫文學探源、聯經出 版公司. 1986. pp.71-165. 此外，亦可參見嚴一萍撰．殷 栔徵嫛·中國醫學之起源考略, 載於《嚴一萍先生全集》(甲 編)。藝文印書館. 1991． p.346。此文指出：“甲骨文沒有 “醫”字, 古時是巫醫連稱的，《論語》說：‘南人有言曰：“人 而無恒，不可以作巫醫。”可見孔子之世，巫醫還屬同類。 追溯遠古，醫術實自巫術孕育而來。所以古籍相傳，最初作 醫的是巫彭與巫咸。”

27）(淸)阮元校刻。《十三經注疏(附校勘記)》(下冊)《春秋左傳 》卷第二十《文公十八年》. p.1861.

28）(淸)阮元校刻。《十三經注疏(附校勘記)》(下冊)《春秋左傳 》卷第三十一《襄公十年》. p.1947. 
晉侯有疾，鄭伯使公棌僑如晉聘，且問疾。叔向問 焉，日：“寊君之疾病，卜人日：“實沈、臺駘爲崇。” 史莫之知, 敢問此何神也? ”子產日：“昔高辛氏有二 子。伯日：閍伯, 季曰: 實沈。居于曠林, 不相能也。 日尋干戈, 以相征討。后帝不藏, 遷関伯于商巨(丘), 主辰。商人是因, 故辰爲商星。遷實沈于大夏, 主參。 唐人是因, 以服事夏商。”

\section{又《國語·晉語八》亦云30：}

鄭簡公使公棌成子來聘，平公有疾，韓宣子贊授客 館。客問君疾, 對曰： “臭君之疾久矣, 上下神祇無不 徧諭, 而無除。今夢黃熊入於寝門, 不知人殺乎, 抑厲 鬼邪?”産日：“以君之明, 子篇大政, 其何庽之 有?”

由此二文不難得知, 於晉本公有疾時, 不惟召卜人 占病，並且“徧猃上下神祇”31)。

此外, 《春秋左傳·哀公六年》亦云32）：

初, [楚]昭王有疾，上曰：“河爲崇。”王弗祭。 大夫請祭諸郊。王日：“三代命祀，祭不越望。江、 漢、㫿、章, 楚之望也。禍福之至, 不是過也。不穀雖 不德，河非所獲罪也。”遂弗祭。

\section{又《戰國策·東周》亦云33）:}

趙取周之祭地, 周君患之, 告於鄭朝。鄭朝日: “君 勿患也。臣請以三十金復取之。”周君予之。鄭朝獻之 趙太卜, 因告以祭地事。及王病, 使卜之。太卜譴之

29）(清)阮元校刻。《十三經注疏(附校勘記)》(下冊)《春秋左傳 》卷第四十一《昭公元年》. p.2023.

30）(周)左丘明撰，鮑思陶點校。《國語》爸第十四《晉語入.鄭 簡公使公棌成子來聘》. 齊鲁書社. 2005. pp.233-234.

31） 林志鵬. 殷代巫琴活動犐究. 臺灣大學中文所碩土論文. 2003. pp.65-69.

32）（清)阮元校刻。《十三經注疏(附校勘記)》(下冊)《春秋左傳 》第五十八《哀公六年》. p.2162.

33）(漢)劉向集錄，范洋雍箋登，范邦瑾拹校。《戰國策篦登》 (上冊) 卷第一《東周凡二十八章·趙取周之祭地》。上海古籍 出版社. 2006. pp.66-67.
日：“周之祭地爲崇。”趙乃還之。

又《晏子春秋·內篇雜下》亦云 34$)$ ：

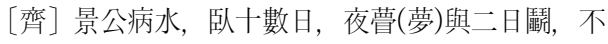
勝。晏子朝, 公曰: “夕者瞢(夢)與二日鬪, 而寊人不 勝, 我其死乎?”晏子對日：“請召占瞢(夢)者。”出于 閨，使人以車迎占萺(夢)者。至，日：“曷爲見召?”晏 子日：“夜者，公瞢(夢)二日與公鬫，不勝。公日：“宾 人死乎?’故請君占瞢(夢), 是所営也。”占瞢(夢)者 日: “請反(翻)具(其)書。”晏子日: “曲反(翻)書。公所 病者, 陰也, 日者, 陽也。一陰不勝二陽, 故病將已 (愈)。以是對。”占瞢(夢)者入，公曰: “寊人瞢(夢)與

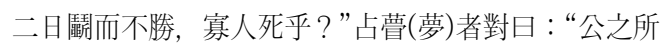
病, 陰也, 日者, 陽也。一陰不勝二陽, 公病將已( 愈)。”居三日, 公病大愈, 公且(將)賜占瞢(夢)者。

據此幾文可見，於兩周時期，便有巫者問病卜災的 事實。不寧唯是, 古人認爲疾病爲鬼神降崇所致, 故往 往卜問作崇之鬼神。

\section{3. 祝由之術}

再次, 於兩周時期的中國古籍文獻中, “祝由”巫術 之例35), 則不乏見之, 如《春秋公羊傳·隱公四年》, 於“於鍾巫之祭焉，斌隱公也。”36)之下，何休其疏 云37）:

34）吳則虞編. 《晏子春秋集釋》(下冊)卷第六《內篇雜下.景公

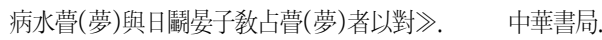
1962. pp.382-385.

35）此種“祝由”巫術之法，乃爲古代以祝禱符咒治病的方術，即 祝說病由以治病之一種巫術方法。後世稱以符咒穰病者営 “祝由科”。參見漢語大詞典編輯委員會編. 漢語大詞典. 祝由 (第七冊)．漢語大詞典出版社．1991-1994．此外，若視《 說文解字·福》字, 於“檑, 祝福也。从示, 政聲。”之下, 其段注云：“惠氏士奇日：“《素問》黄帝日：“古之治病，可 祝由而已(止)。”祝由，郎祝福也。已，止也。”(清)段玉裁 注.《說文解字注》第一篇注上《福》. p.6.

36）(清)阮元校刻。《十三經注疏(附校勘記)》(下冊)《春秋公羊 傳》替第二《隐公四年》. p.2205.

37）(清)阮元校刻。《十三經注疏(附校勘記)》(下冊)《春秋公羊 傳》卷第二《隐公四年》. p.2205. 
巫者，事鬼神，禱解以治病、請福者也。男日： 㠫，女日：巫。

又《春秋左傳·哀公六年》亦有記載，其云38）：

初，一楚］昭王有疾，上曰：“河爲崇。”王弗祭。 大夫請祭諸郊。

又《春秋左傳·昭公元年》亦云39）：

晉侯有疾，鄭伯使公孫僑如晉聘，且問疾。叔向問 焉，日：“寡君之疾病，卜人日：“實沈、臺駘爲崇。” 史莫之知，敢問此何神也? ”子產日：“……是觀之, 則實沈，參神也。……是觀之，則臺駘，汾神也。抑 此二者，不及君身。山川之神，則水旱㾖疫之災，於是 乎禜之。”

此文中的“禜”祭，則謂祓禳㾖疫於山神河伯的一種 巫術祭儀。

不寧唯是, 《尚書·金縢》記載武王有病, 長久不 愈，周公乃設壇向天神、租神祈禱之事，其云40）:

既克商二年，王有疾，弗豫。二公日：“我其爲王穆 (敬)卜”周公日: “未可以戚我先王。”公乃自以爲功 (事), 爲三壇同墠。爲壇於南方, 北面, 周公立焉。植 (置)璧秉珃，乃告大(太)王、王季、文王。史乃冊祝 日：“惟爾元孫某，遘厲虐疾。若爾三王，是有不子之 責于天, 以旦代某之身。予仁若考(孝), 能多材多藝, 能事鬼神。乃元孫不若旦多材多藝，不能事鬼神。乃命 于帝庭，敷佑四方，用能定爾子孫于下地。四方之民， 罔不祗畏。嗚呼！無墜天之降寶命，我先王亦永有依 歸。今我師命于元龜, 爾之許我, 我其以璧與珪, 歸俟 爾命。爾不許我，我乃屏璧與珪。”乃卜三龜，一習 (襲)吉。啟篇見書, 乃并是吉。公日：“體，王其罔

38）（清)阮元校刻。《十三經注疏(附校勘記)》(下冊)《春秋左傳 》卷第五十八《哀公六年》. p.2162.

39）(淸)阮元校刻。《十三經注疏(附校勘記)》(下冊)《春秋左傳 》然第四十一《昭公元年》. pp.2023-2024.

40）(淸)阮元校刻。《十三經注疏(附校勘記)》(上冊)《尚書·周書 》卷第十三《金縢》. pp.196-197.
害。予小子新命于三王，惟永終是圖，茲做俟，能念予 一人。”公歸，乃納冊于金滕之貝中。王翼日乃疹。

又《史記·魯周公世家》亦記載相同的內容，其 云41）:

武王克殷二年，天下未集，武王有疾，不豫，韋臣 懼，太公、召公乃結(穆)卜。周公日：“未可以戚我先 王。”周公於是乃自以爲質，設三壇，周公北面立，戴 璧秉圭，告于太王、王季、文王。史策祝日：“惟爾元 孫王發，勤勞阻(淹)疾。若爾三王，是有負子之責於 天，以旦代王發之身。旦巧能，多材多蓺(藝)，能事鬼 神。乃王發不如旦多材多勢(藝)，不能事鬼神。乃命于 帝庭，敷佑四方，用能定汝子孫于下地，四方之民，罔 不敬畏。無丞天之降葆(寶)命，我先王亦永有所依歸。 今我其師命於元龜，爾之許我，我以其璧與主歸，以俟 爾命。爾不許我，我乃屏璧與圭。”周公已令史策告太 王、王季、文王，欲代武王發，於是乃師三王而卜。卜 人皆曰：吉，發書視之，信吉。周公喜，開篇，乃見書 遇吉。周公入賀武王日 : “王其無害。旦新受命三王, 維長終是圖。茲道能念予一人。”周公藏其策金膫實 中，誡守者勿敢言。明日，武王有疹。

據此二文可以得知，周公爲武王的久病析禱，請求 以身代，不久武王病愈 ${ }^{42)}$ 。尤其，司馬遷引《《尚書. 金搼》而著《魯周公世家》，其意乃在表彰周公文德， 故上引二文，其形式近同43）。

41）(漢)司馬遷撰，(宋)裴駆集解，(唐)司馬貞索隱，(唐)張守節正 義. 《史記》(第五冊)卷第三十三《魯周公世家》. pp.1516 -1518 .

42）參見李學勤. 文物中的古文明·《尚書·金滕》與楚簡禧辭. 商 務印書館．2008．pp.408-412．此外，於《史記·魯周公世 家》又記載周公爲成王的疾病祈禧，請求以身代，不久成王 病愈之事，其云：“初，成王少時，病，周公乃自揃其蛋沈 之河，以祝於神日：“王少未有識，奸神命者乃旦也。”亦藏 其策於府。成王病有疹。” (漢)司馬遷撰, (宋)裴馹集解, (唐)司馬貞索隱，(唐)張守節正義. 《史記》(第五冊)卷第三 十三《魯周公世家》. p.1520.

43）除此二文之外，類似此記載，亦可見於2008年7月入藏於淸 華大學的《淸華大學藏戰國竹簡(壹)》之中。此淸華大學藏 戰國竹簡，一般簡稱“清華簡”，其中《周武王有疾周公所自 以代王之志(金縢)》篇，共14枚，三道編，完簡長45䔩米， 其年代爲戰國中晚期。茲舉其前段記載爲例，其簡文日： 
除此之外, 《論語·述而》亦有其記載, 其云44）:

子疾病，子路請禱。子日：“有諸?”子路對曰：“有 之。昩日：“禱爾于上下神祇。”子曰：“上(丘)之禱久 矣。”

又《韓非子·外儲說右下》亦云45)：

一曰：秦襄王病，百姓鳻之禱。病㸝，殺牛塞(賽) 禱。郎中閻遏、公孫衍出見之, 日: “非社臘之時也, 奚自殺牛而祠社？”怪而問之。百姓曰：“人主病，爲之 禱。今病愈, 殺牛塞(賽)禱。”

又《墨子·天志中》亦云46)：

天子有疾病禍崇，必齋戒沐浴，潔爲酒醴染盛，以 祭祀天鬼, 則天能除去之。

又《管子・小問》亦云47)：

[齊］桓公踐位，令燢社塞(賽)禱。祝鳥、已疪獻

“武王既克蜸(殷)三年, 王不庩(豫)又(有)尼(遲)。二公告 周公日: ‘我元(其)爲王穆(敬)卜。周公日: ‘未可以感(戚) 豦(吾)先王。'周公乃爲三坦(壇)同军(墠), 爲一坦(壇)於 南方，周公立女(焉)，秉璧岶(戴)球。史乃冊祝告先王日：

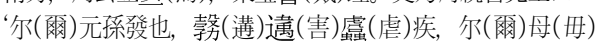
乃有借(負)子之責才(在)上? 隹(惟)尔(爾)元棌發也, 不若 但(日)也。是年(侯)若万(巧)能, 多态(才)多埶(藝), 能事 票(鬼)神。命于帝盖(廷), 尃(溥)又(有)四方, 以䣄(定)尔

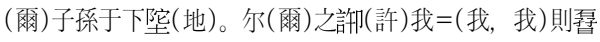
(晉)璧與珪。尔(爾)不我彻(許), 我乃以璧與球䢜(歸)。 周公乃內(納)开(其)所爲社(功)自以弋(代)王之攽(說)于金 紛(滕),之匮, 乃命執事人日: ‘勿敢言。’(此簡文見於《清華 大學藏戰國竹簡(壹)·周武王有疾周公所自以代王之志(金滕) 》第1簡至第6簡中間) ”李學勤主編.《清華大學藏戰國竹簡 $($ 壹 $) 》($ 下冊 $)$ 《䆁文注釋·周武王有疾周公所自以代王之志 (金滕)》. 中西書局. 2010. pp.157-161.

44） (清) (元元校刻。《十三經注疏(附校勘記)》(下冊)《論語》卷 第七《述而》. p.2484.

45）梁砶雄《韓子淺解》(下冊)第三十五篇《外儲說右下:二》. 中華書局. 1960. p.336.

46）(淸)孫詒讓撰, 棌殷治點校.《墨子閒詁》(上冊)卷第七《天 志中》. p.198.

47) 黎翔鳳撰, 梁運華整理、《管子校注》(中冊)卷第十六《小問 》. 中華書局. 2004. pp.967-968.
胙。祝日：“除君苛疾，與若(似)之多虛而少實。”

又《春秋左傳·昭公二十年》亦云48）:

齊侯疥，遂痁(瘧)，期而不疹，諸侯之賓問疾者多 在。梁巨(丘)據與裔欵言於公日：“吾事鬼神豐，於先 君有加矣。今君疾病, 爲諸侯憂, 是祝、史之罪也。諸 侯不知, 其謂我不敬, 君盍誅於祝固、史㗊以辭賓? ” 公說(悅), 告晏子。

此文與上引《管子·小問》, 均闡述祝有祝人無病長 壽及祈死的二種職能 49 )。

不寧唯是, 《尚書·大誥》亦云50) :

天亦惟用勤眥我民，若有疾，予曷敢不于前寧人敒 受休畢。

孫詒讓在《尚書駢枝·大誥》中，此文的“畢”作新禱 解51), 其云52) :

48）(清)阮元校刻。《十三經注疏(附校勘記)》(下冊)《春秋左傳 》第四十九《昭公二十年》. p. 2092. 此外, 此文又見於 《晏子春秋·內篇諫上》中, 其云：“[齊］景公扴且㗔，期 年不已(疹)。召會愦、梁丘據、晏子而問焉, 日: ‘宾人之病 病矣, 使史固與祝伦巡山川宗廟, 犠牲玨璧, 莫不備具, 數 其常多先君桓公，桓公一則宾人再。病不已(疹)，滋甚，予 欲殺二子者以說于上帝，其可乎?’會譴、梁丘據日：“可。” 晏子不對。公日: ‘晏子何如?'晏子日: ‘君以视爲有盆乎? 公曰: ‘然。”吳則虞編。《晏子春秋集釋》(上冊)卷第一《 内篇諫上·景公病久不愈欲誅祝、史以謝晏子諫》。 pp.42-45. 又在《晏子春秋·外篇》中, 亦云：“ [齊] 景公 疥遂痁(瘧), 期而不疹。墸侯之賓, 問疾者多在。梁丘據、 裔款言于公日：吾事鬼神，豐于先君有加矣。今君疾病，爲 諸侯憂，是祝、史之罪也。諸侯不知，其謂我不敬，君盍誅 于祝固、史㗊以辭賓? ’公說( 悅)，告晏子。”吳則虞編《晏 子春秋集䆁》(下冊)卷第七《外篇, 景公有疾梁丘據、裔款請 誅祝、史晏子諫》. pp.446-450。除此之外，亦可參見馬承 源主編.上海博物館藏戰國楚竹書(六).競(景)公瘧.上海古 籍出版社. 2007. pp.157-191. 不寧唯是，亦可參見銀雀山 漢墓竹簡整理小組編. 銀雀山漢墓竹簡(壹)·晏子. 文物出版 社. 1985. pp.93-94.

49）參見林志鵬. 殷代巫琴活動研究. 臺灣大學中文所碩土論文. 2003. pp.90-91.

50）(清)阮元校刻。《十三經注疏(附校勘記)》(上冊)《尚書·周書 》第十三《大誥》. p.199.

51）陳邦賢. 中國醫學史·上古的醫學. p.8.

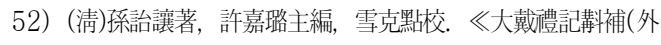


又实(審)玩此文, 古者攘除疾病, 蓋或謂之畢, $\cdots \cdots$ 。謂對于前文人受其休美而畢除其疾，《[尚 書· ] 康誥》亦云：“若有疾, 惟民其畢棄各。”, 畢棄 各, 即攘除棄去疾病也。兩經互證, 足知其義。《書 》、《禮》舊說並通釋畢営終盡, 則與疾病不相涉, 而 “若有疾”句爲贅語矣。

由此幾文可知，於兩周時期，巫者曾用祈禱的方 式，即施行“祝由”之法，以乞求神靈寬恕的事實53)。

此外, 古人將一切的疾病, 皆認爲惡鬼作崇或受神 靈懲罚的結果, 故巫者以法術驅除縓身的惡鬼, 以排難 解憂且脫離其桎梏。此時巫者或用詛咒法, 祓禳山川邪 鬼作崇的㾖疫54), 故上古時巫術對於患者, 至少具有

四種)》(全一冊)《尚書駢枝·大誥》。 中華書局. 2010. pp.128-129.

53）年鍾鑒，張踐合著。中國宗敉通史(上冊)。社會科學文獻出版 社. 2000． p.208. 此外，巫者以“祝由”之法攘除疾病的内 容, 於今本《黃帝內經》之中, 亦偶有所見, 如《黄帝內經 素問·移精變氣論》便有其記載, 其云 : “黄帝問日: ‘余聞古 之治病, 惟其移精變氣, 可祝由而已(瘾)。今世治病, 毒藥 治其內, 鍼石治其外, 或愈或不刽, 何也?’歧伯對日：“徃 (往)古人居禽獸之閒(間)，動作以避寒，陰居以避暑，內無 脊慕之累, 外無伸官之形, 此恬信之世, 邪不能深入也。故 毒藥不能治其內, 鍼石不能治其外, 故可移精视由而已( 瘺)。”(唐)王冰次注，（宋)林億等校正. 《黃帝內經素問》 (附䆁文)卷第四《移精變氣論》, 載於《文淵閣四庫全書》 第七三三册《了部三九醫家類》。臺灣商務印書館. 1983-1986. pp.49-50. 不寧唯是, 《靈樞經:睋風》亦 云：“ [黃帝曰：］其母(無)所遇邪氣, 又冊(無)怵惕之所 志, 卒然而病者, 其故何也? 唯有因鬼神之事乎? ’ 岐(歧)伯 日: “此亦有故邪, 留而未發, 因而志有所惡, 及有所慕, 血 氣内亂，兩氣相搏。其所從來者微，視之不見，聽而不聞， 故似鬼神。'黄帝日：“其祝［由］而已(㾙)者, 其故何也?’ 岐(歧)伯日：“先巫者, 因(固)知百病之勝, 先知其病之所從 生者, 可祝 [由]而已(癒)也。”(唐)王冰次注, (宋)史崧校 正音釋。《靈樞經》替第九《賊風》, 載於《文淵閣四庫全 書》第七三三冊《子部三九醫家類》. p.394. 據此二文不 難得知，於今本《黄帝內經》之中，亦記述上古的巫者以 “祝由”之法治病的內容。

54）有關巫者用詛咒法祐嚷山川邪鬼作崇的㾖疫的事實, 如《說 苑辨物》便有其記載, 其云：“扁鵲曰：'入言鄭際秦越人能 活太子。'中庶子難之日：吾聞上古之舀毉者日：苗父。苗

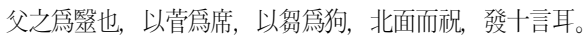
諸扶而來者，舉而來者，皆平復如故。子之方能如此乎?'扁 鵲曰: “不能。”(漢)劉向撰，向宗魯校登。《說苑校登》尞 第十八《辨物》. p. 471 . 此外, 此種以詚咒法治病的情形, 如在中國少數民族的巫醫療法之中，亦可見之。對此，宋兆 麟在《巫與巫術》一書中，眯提及廣東海豐地區巫者的詛咒
精神治療上的作用55)。

由是觀之，兩周時期的巫者，便運用向神靈祈禱或 驅逐鬼神的醫療巫術。此種巫術性醫療行爲，雖無濟於 事, 但一方面一定有安慰病者心理的功效。

\section{4. 逐疫除凶}

巫者擔任的疾疫之防治工作，則有文獻所謂的“逐疫 除凶” 與“儺”的兩大類，即水寝(以水洗寝)、毆寝(毆除 穢物)、搜寝(貙除蟲物及不祥疾疫)等的祓除活動, 以 及儺舞驅鬼的活動。不僅如此, 若遭遇放愠毒人之術 時, 古人便實行治䀇之法。

此處介紹兩周時期巫者的此種防疫除风活動，並略 加敘述於下。

\section{1) 逐疫除凶}

古時巫者曾擔任疾疫之防治的職責, 則從事水寝、 毆寝、搜寝等的逐疫除凶活動。

首先考察逐疫活動，於先秦的古籍文獻中，有關逐 疫的記載屢見不鮮, 如《周禮·男巫》便有其記載, 其 云56)：

男巫：……冬堂贈, 無方無等。春招弭, 以除疾 病。

其下杜子春云：“堂贈謂逐疫也。”57)

又《周禮·女祝》亦有記載，其云58）：

療法巫術, 其云: “廣東海豐地區漢族遇到小孩患眼紅病, 則認定是赤目神作崇，必行巫術，巫師或成年人在紙上寫一 首打油詩 : ‘赤目赤目神，你是揚州掃地人。只因掃地打瞎 目，今來變作赤目神。我今天來點破你，千年萬載不相尋。” 寫畢，把紙貼在門柱上，路人看了念一遍，小孩的眼疾就會 痉愈。這實際是以神名當种進行詛咒的模仿巫術。由此看 出，遠古醫療疾病的重擔只能落在巫師的肩上，這是史前時 代巫醫結合的歷史背景。”宋兆麟、巫與巫術·巫醫. 四川民族 出版社. 1989. p.270.

55）羊鍾鑒, 張践合著. 中國宗教通史(上冊). p.208.

56）(清)阮元校刻。《十三經注疏(附校勘記)》(上冊)《周禮·春官 宗伯》觉第二十六《男巫》. p.816.

57）(清)(阮元校刻。《十三經注疏(附校勘記)》(上冊)《周禮·春官 宗伯》卷第二十六《男巫》. p.816.

58）(清)阮元校刻。《十三經注疏(附校勘記)》(上冊)《周禮·天官 冢宰》卷第入《女祝》. p.690. 
女祝：……掌以時招、梗、禬、禳之事，以除疾 殊。

此文中的招、梗、禬、禞䍃四種除疾的祭名，則招 祭爲招取善祥, 梗祭爲豫災之祭, 禬、禞乃䍃除災之 祀。據此不難得知, 此種祭祀, 均屬於驅逐疾疫的巫術 行爲。

不寧唯是, 亦有關於除凶的記載, 如《春秋左傳·昭 公十八年》便有其記錄，其云59）：

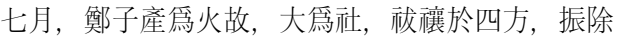
火災，禮也。乃簡兵大蒐，將爲菟除。

孔穎達疏於其下，其云60）：

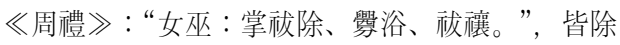
风之祭。徧於四方之神，如《尚書》：“咸柣無文，苟 可祭。” 者, 悉皆祭之, 所以振訊, 除去火災, 禮也。 嫌多祭非禮，故禮之。

又《禮記·檀弓下》亦云61）：

君臨臣喪, 以巫、祝桃茢執戈, 惡之也, 所以異於 生也。

此處的桃茢執戈等的物品, 古人認爲皆能辟邪除凶 之物 62 )。

59）(清)阮元校刻。《十三經注疏(附校勘記)》(下冊)《春秋左傳 》第四十八《昭公十八年》. p.2086.

60）（清)阮元校刻。《十三經注疏(附校勘記)》(下冊)《春秋左傳 》第四十八《昭公十八年》. p.2086.

61）(清)阮元校刻。《十三經注疏(附校勘記)》(上冊)《禮記》卷 第九《檀弓下》. p.1302.

62）此文的記載之外，有關巫者使用的祓凶辟邪道具的記述，於 《春秋左傳·裹公二十九年》之中, 亦有其記載, 其云 :

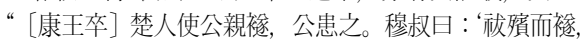
則布幣也。’乃使巫以桃、茢先祓殯。楚人弗禁，既而悔 之。”(清)阮元校刻。《十三經注疏(附校勘記)》(下冊)《春 秋左傳》卷第三十九《襄公二十九年》. pp.2004-2005. 又 在《藝文類聚·菓部上》收錄的《莊子》佚文中，亦云：“《 莊子》: ‘插桃枝於戶, 連灰其下, 童子入不畏, 而鬼畏之。 是鬼智不如童子也。”(唐)貙陽詢撰，汪紹桗校、《㙯文類聚 (附索引)》(下冊)卷第入十六《菓部上:桃》。 上海古籍出版
由此可知，於兩周時期，不惟有驅逐疾疫的巫術行 爲，亦有除凶社殊的巫術活動。

\section{2) 儺舞活動}

除如前所陳的逐疫除凶的活動之外，亦有醫療疾病 時驅捤庽鬼的巫術祭祀儀式。此種巫術祭祀儀式, 於古 代稱之爲“儺” $\left.{ }^{2} 3\right)$ ，如《周禮·方相氏》便有其記載，其 云64)：

方相氏：掌蒙熊皮，黃金四目，玄衣朱裳，執戈揚 盾, 帥百隸而時難(儺), 以索室歐(歐)疫。大喪, 先 嚂，及墓，入壙，以戈擊四隅，歐(歐)方良。

方相氏為在周代掌管驅除㿔疾的巫官。此方相氏的 面容，則頭戴繪有“黃金四目”的面具，蒙著熊皮，上著 黑衣, 下穿紅裳, 一手執戈, 一手揮舞盾牌, 全貌戊 裝，率領100名屬下，便進行居室或墓壙各處搜索，以 驅逐疫瘦之氣65)。由此可知, 儺爲頭戴面具而驅捤厲 鬼的巫術儀式之一。

又在《論語·鄉黨》的記載：“鄉人儺，朝服而立於 阼階。”66)之下，朱喜的《集註》云67)：

社. 1965. p.1468. 由此可知，此文中所載的桃効執戈等的 物品，皆爲巫者使用的辟邪物。

63）此“傼”儀式，古人認爲，於醫療疾病時驅替厲鬼的巫術祭祀 儀式。此種見解，亦可參考人類學的報告，其云：“澳洲錫 隆(Ceylon)土人的“鬼神舞者(Devil-Dancers)', 常常把一 個木製面具戴在頭上，面具上有大的眼睛，有象牙一樣長的 尖銃牙齒, 有诉子一樣的大鼻子, 有老虎一樣的大口。還有 一個面貌扮得似老虎的怪人, 旁人擊起在兩側龍打的鼓, 怪 人在中間不停地跳舞。這樣裝扮成神的形象來跳舞, 土人相 信可以驅除病人周圍的鬼怪。”梁釗䐆. 中國古代巫術 - 宗敉的起源和發展. 中山大學出版社. 1989. p.163. 亦可參 見Walter Hutchinson(沃爾特哈欽森). Customs of the World, Vol. I -- a popular account of the manners, rites and ceremonies of men and women in all countries : 世界風俗·CEYLON(錫隆)。 Neeraj Publishing House. 1984. p.425.

64）(清)阮元校刻。《十三經注疏(附校勘記)》(上冊)《周禮·春官 宗伯》爸第三十一《方相氏》. p. 851 .

65）此處敘述的方相氏之職, 其與男巫在冬儺時將寝堂的疫㾖驅 逐至郊外的“索室殿(歐)疫”, 應互有關聯。林志鵬、殷代巫 梘活動研究. 臺灣大學中文所碩土論文. 2003. pp.273-274.

66）(宋)朱喜. 《論語集註大全》参第十《鄉黨》。保景文化社. 1986. pp.208-209.

67 ）(宋)朱喜.《論語集註大全》谷第十《鄉黨》. pp.208-209. 
尸子曰：“有醫竘者，秦之良醫也。爲［楚］宣王割 痤, 爲[魏] 惠王療痔, 皆愈。張子之背腫, 命竘治 之。謂醫竘日：“背非吾背也，任子制焉。’治之，遂 愈。竘誠善治疾也, 張子委制焉。夫身與國, 亦猶此, 必有所委制，然後治。”

又《周禮·占夢》亦有其記載，其云68）：

占夢：……透令始難(儺)歐(驅)疫。

鄭康成注於其下，其云69）：

令，令方相氏也。難，謂執兵以有難卻也。方相 氏，蒙熊皮，黃金四目，玄衣朱裳，執戈揚盾，帥百隸 爲之, 歐疫庽鬼也。故書難或爲儺。

由此不難得知，“儺”的本義字爲“難”70)，且儺舞爲 一種驅鬼社邪的巫術行爲。

此外，於《太本御覽·禮儀部》收錄的《莊子》佚文 中，亦記載巫者驅捤厲鬼的巫儀內容，其云71）：

游島問雄黃日：“今逐疫出魅，擊鼓呼噪，何也？” 雄黃日：“黔首多疾，黃帝氏立巫咸，使黔首沐浴齋 戒, 以通九竅。鳴鼓振鐸, 以動其心。勞形趁(趨)步, 以發㓌陽之氣。飲酒茹葱以通五藏(藏)。夫擊鼓呼噪, 逐疫出魅鬼，黭首不知，以爲魅崇也。”

據此可知，於《太平御覽》的《莊子》佚文中，亦 可得見巫者的儺儀巫術活動。

由此觀之, “儺”爲頭戴面具而求醫治病、逐鬼駱疫

68）(清)阮元校刻。《十三經注疏(附校勘記)》(上冊)《周禮·春官 宗伯》第二十五《占夢》. p. 808 .

69）(淸)阮元校刻。《十三經注疏(附校勘記)》(上冊)《周禮·春官 宗伯》替第二十五《占夢》. p. 808 .

70）對於“儺”的本義字鹪“難”的解釋，可參閱《說文解字·儺》 字, 於“辟, 行有節也。从人, 難聲。《詩》日：佩玉之 儺。”之下, 其段注云：“按此字之本義也，其檄(歐)疫字，

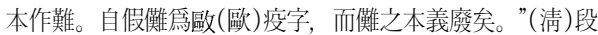
玉裁注.《說文解字注》第入篇注上《儺》. p.372. 據此可 見，“儺”的本義字䉆“難”，其義亦有展(歐)疫之意。

71）(宋)李助等撰、《太平御覽》(第三冊)怣第五百三十《禮義部. 儺》. 中華書局. 1960. pp.2405-2406.
儀式中所用的活動，即鷂一種防疫的巫術活動72）。

\section{3）放蛊毒人之術}

於中國巫術傳統上，則有較爲神秘且令人懼怕的一

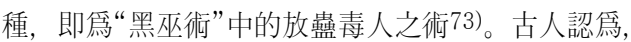
因巫者運用此術，使人產生疾病，又使人至於喪亡，故 盡力防止其受害。

首先論先秦的放蛊毒人之術，如《春秋左傳·昭公元 年》則有其記載，晉侯求醫於秦，秦伯使醫和視之，醫 和曰：“病不可営也，是謂近女室，疾如瞌。非鬼非 食，惑以喪志。良臣將死，天命不祐。”74)之後，又與 趙孟談論此事，其文曰75）：

趙孟曰：“何謂蛊？”對曰：“滥溺惑亂之所生也。於

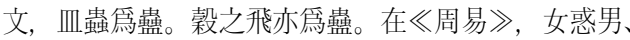
風落山，謂之盢(巽下三艮上三)。皆同物也。”

此文之下，孔穎達疏云76)：

以毒藥藥人，令人不自知者，今律謂之瓂毒。

《周易·葢》亦云77）

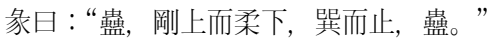

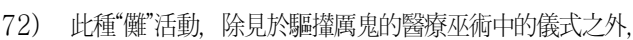
又在古代巫者的喪葬巫術活動中，亦可見之。詳見拙著．殷 商甲骨卜辭所見之巫術·啔葬巫術方面(增訂本) , pp.239-250.

73）對人有害的巫術，即企圖使人生病、死亡，或使之遭遇荻難 的法術, 則稱之舀“黑巫術(Black Magic)”。參見謝康. 中國 古代巫術文化及其社會功能(上、下)。 中華文化復興月刊。 1976(1). pp.40-50, 1976(2). pp.32-40. 另見宋兆麟、巫 與巫術. pp.235-242. 此種黑巫術, 又稱惡意巫術，如禁 人、詛咒、放蛊、下毒等，皆基於造螎於人。因爲此種巫術 執行一種在技術上可能的行動, 而使對方蒙受一定的惡果, 並且以害人爲目的，往往造成危害個人、家庭或社會的利 益, 故使人望而生畏。

74）(清)阮元校刻。《十三經注疏(附校勘記)》(下冊)《春秋左傳 》替第四十一《昭公元年》. p.2024.

75）(清)阮元校刻。《十三經注疏(附校勘記)》(下冊)《春秋左傳 》怣第四十一《昭公元年》. p.2025.

76）（清)阮元校刻。《十三經注疏(附校勘記)》(下冊)《春秋左傳 》卷第四十一《昭公元年》. p.2025.

77）(清)阮元校刻。《十三經注疏(附校勘記)》(上冊)《周易》卷 第三《籃》. p.35. 
孔穎達疏於其下，日78）：

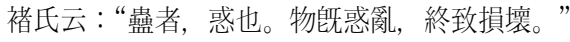

由此可見，放蕰毒人之術法，則淵源悠久。

不寧唯是，對於中國古代原始毒人巫術的情形，如 《論衡·言毒》便有其記載, 其云 79$)$ :

夫毒, 太陽之熱氣也，中人人毒。……陽之地， 人民促急, 促急之人, 口舌爲毒。故楚、越之人, 促急 捷疾, 與人談言, 口唾射人, 則人脤(䐜)胎(脹), 腫而 爲創(瘡)。南郡極熱之地，其人祝樹樹枯，唾鳥鳥陮。 巫咸能以祝延(移)人之疾、愈人之禍者, 生于江南, 含 烈氣也。

此種記載未免誇大, 即使如此, 卻充分反映秦代的 社會心理80)。

此種放蛊毒人之方法極其爲多, 例如金蛀蛊、疳

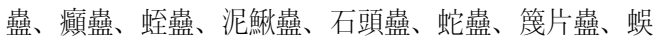
蚣蒀等等 81 )。此外, 亦有養鬼放鬼作害於人, 以及致 人於死地爲莫上之樂的黑巫術等, 甚爲無楷, 此種放蛊 毒人巫術之例甚多, 不勝枚舉。

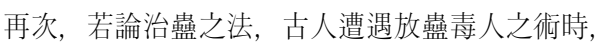
並不束手無策, 乃實行治輼之法, 以盡力迴避其受害。

首先，有關巫術性治蛊之術的記錄，如《周禮·犁氏 》便有其記載，其云82：

翦氏：掌除犟物。以攻禜攻之, 以莽草熏之。凡庶 蝹之事。

\section{又《周禮·壼涿氏》亦云83)：}

78）(清)阮元校刻。《十三經拄疏(附校勘記)》(上冊)《周易》卷 第三《蛊》. p.35.

79）黄睡撰。《論衡校䆁(附劉盼遂集解)》(第三冊)卷第二十三《 言毒》. 中華書局. 1990, p.950.

80）徐富昌. 睡虎地秦簡码究. 文史哲出版社. 1993. pp.304-305.

81）宋兆麟. 巫與巫術. p.230.

82）(清)阮元校刻。《十三經注疏(附校勘記)》(上冊)《周禮·秋官 司寇》第三十七《丞氏》. p.889.
壳溷氏 : 掌除水蟲，以炮土之鼓毆(驅)之，以焚石投 之。若欲殺其神, 則以牡棹(枯)午(五)貫象齒而沈之, 則其神死，淵爲陵。

又《周禮·庶氏》亦云84）:

庶氏: 掌除毒䓝。以攻說禬之, [以]嘉草攻之。 凡敺(驅)蠱, 則令之比之。

其下鄭玄注云 85$)$ ：

毒蛊, 蟲物而病害人者。……攻說, 新名, 祈其神 求去之也。嘉草, 藥物, 其狀末聞。攻之, 謂燼之。

此文中的“嘉草”, 今人胡新生認爲特指治蠱的“襄 荷”86)。

據此《周禮》的三文不難得知, 巫術性治蛊之法有

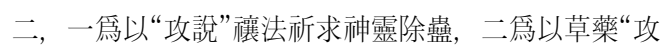
之”而燻蟲殺蛊87）。因此，於中國先秦時期，不僅流行 放蛊毒人之術, 又有巫術性治蛊之法。

不寧唯是，除此種巫術性治罝之外，亦有勸時王禁 止放蓝毒人之術的記錄，如在傳爲周初呂望(即姜太公) 所撰的《六楿・上賢》篇中, 便有周文王問姜太公治國 之道的內容, 其中則有太公回答王人者應慎重六賊、七 害之事，其云88）

[太公曰：］“七害者，……七日：䳕方異技，巫 蛊左道, 不祥之言, 幻惑良民, 王者必止之。”

83）(清)阮元校刻。《十三經注疏(附校勘記)》(上冊)《周禮·秋官 司寇》卷第三十七《瞉溷氏》. p.889.

84）(清)阮元校刻。《十三經注疏(附校勘記)》(上冊)《周禮·秋官 司寇》谷第三十七《庶氏》. p. 888.

85）(清)阮元校刻。《十三經注疏(附校勘記)》(上冊)《周禮:秋官 司晸》卷第三十七《庶氏》. p.888.

86）胡新生. 中國古代巫術. 山東人民出版社. 1999 , pp. $444-445$.

87）鄧殿耀. 中國巫蒀考察. 上海文藝出版社. 1999. p.48. 亦可

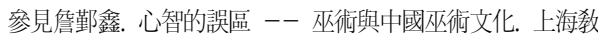
育出版社, 2001. pp.641-642.

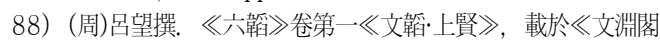
四庫全書》第七二六冊《子部三二: 兵家類》。臺灣商務印書 館. 1983-1986. p.15. 
由此可知, 於王人者應慎重的六賊、七害之事中, 便有放鳁毒人之術，且勸王止之。

尤其，如《禮記·王制》便記載周代制定的治䓝之 法，其云89）：

析(巧)言破律，亂名改作，執左道以亂政，殺。…… 假於鬼神、時日、卜筮以疑衆，殺。

其下鄭玄注云 : “左道，若巫疊及俗禁。”90) 由此可

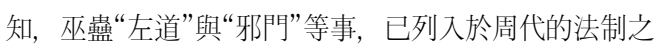
中, 乃變爲嚴厲懲治之對象 91 。

由此觀之, 於兩周時期, 隨著中央王朝的逐漸確 立, 又基於維護統治者的利益, 原始時代的宗教、政治 並存的局面, 已發生變化, 故制定各種措施, 以防範危 害社會的行営92)。

\section{III. 結 論}

巫者職司交通鬼神，其本身雖不具超乎自然的力 量, 但古人相信巫者可藉鬼神之力以成就諸多事。古代 巫者其主要的活動類型，可分爲交通鬼神、醫療巫術、 救災巫術、生產巫術、求子生育、建築巫術、喪葬巫 術、祝詛放蛊、神明裁判等九項93)。

古代人類，因生產條件極差，於野外勞動時，易受 砍傷、摔傷或蛇蟲咬傷, 因而已具有治療常見外傷病症 的若干知識。由於經驗得知某種草藥對之有必然的療 效, 絻能對證下藥, 故治療外傷的醫療知識, 逈爲愈加 豐富。

即使如此, 於遠古時期, 由於地理環境惡劣, 毒蛇 猛獸横行, 加上生活熯苦, 且衛生條件極差, 故難免疾 病的時常發生。如前所述, 對於常見外傷病症, 古人已 有若干治療的知識。儘管如此, 在鬼种概念充斥時的許 多遠古民族, 對於不易得見之若干病症, 則認爲此種疾

89）(清)阮元校刻。《十三經注疏(附校勘記)》(上冊)《禮記》卷 第十三《王制》. p.1344.

90）(清)阮元校刻。《十三經注疏(附校勘記)》(上冊)《禮記》卷 第十三《王制》. p.1344.

91）鄧殿耀. 中國巫蒀考察. pp.306-307.

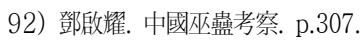

93）詳見拙著。殷商甲骨卜辭所見之巫術巫者的巫術活動(菂訂 本). pp.77-108.
病的來源，乃爲由瘟神、病鬼的綎繞而造成，即所謂鬼 在作崇。

人類在經受各種疾病的苦惱中, 便尋求各種醫療巫 術的方法, 以排難解憂且脫離其桎梏。故召請巫者診 病，巫者則多採取問病卜災等占卜形式，乃診斷爲何鬼 所爲而驅鬼治病。

此種事實，於兩周時期，醫踓已含有專門化、職業 化的性質, 然而在兩周社會中, 仍未盡脫離古人巫醫之 思想。例如在周朝的文獻中，以占卜探知致病之由的記 載，則證實鬼神致病的觀念依然存在。由此亦可知，以 巫術之法療疾的情形, 尚普遍存在於周朝社會之中。

本文則以巫醫之稱、占卜問病、祝由之術、逐疫除 凶等四項重要特色爲主，討論兩周傳世文獻所見的醫療 巫術的內容。此處以其扼要的內容總結如下。

第一, 對於“巫醫之稱”, 若視文獻方面的記載, 於中 國古代, “巫”可稱之爲“醫”或“毉”, 且巫醫不分而屢見 醫與巫的連用詞(複詞)，即“巫醫”之稱。尤其，其中由 “毉”字的字形, 則可見治病之事乃爲古代巫者職事之 一。

第二，若論“占卜問病”的情形，於兩周時期的傳世文 獻中，屢見巫者問病卜災的事實。尤其，古人認爲疾病 爲鬼神降崇所致, 故往往卜問作崇之鬼神。

第三，對於“祝由之術”，於兩周時期，巫者曾用祈 禱、祭祀或驅逐鬼神的醫療巫術等的方式, 即施行“祝 由”之法, 以乞求神靈的寬恕。此種巫術性醫療行爲, 雖無濟於事, 但一方面一定有安慰病者心理的功效。

第四，若就“逐疫除风”方面而言，巫者擔任的疾疫之 防治工作，則有文獻所謂的“逐疫除凶”與“儺”的兩大

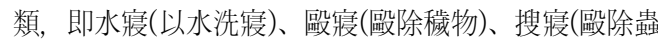
物及不祥疾疫)等的祓除活動，以及儺舞驅鬼的活動。 不僅如此, 若遭遇放蛊毒人之術時, 古人便實行治笽之 法。

綜上所陳，由上述的內容而得知，周代的醫療知識 仍然處於中國醫學的萌芽狀態, 古樸幼稚, 科學與謬誤 參牛, 與巫敎信仰交織一繫。即使如此, 此時的巫醫, 乃開拓壯大醫學的先河, 正因爲如此, 巫醫在中國醫學 上, 則佔有重要的地位。 


\section{徵引書目}

〈古籍文獻〉

1. (周)呂望撰. 六蓞, 載於《文淵閣四庫全書》第七 二六冊《子部三二.兵家類》. 臺灣商務印書館. 1983-1986.

2. (周)左丘明撰, 鮑思陶點校. 國語. 齊魯書社. 2005.

3. (漢)司馬遷撰, (宋)裴駅集解, (唐)司馬貞索隱, (唐)張守節正義. 史記(全十冊). 中華書局. 1959.

4. (漢)劉向集錄, 范祥雍箋䇺, 范邦瑾協校. 戰國策 箋證(全二冊).上海古籍出版社. 2006.

5. (漢)劉向撰, 向宗魯校登. 說苑校證. 中華書局. 1987.

6. (魏)張揖, (淸)王念棌疏登, 陳雄根標點. 廣雅疏 證. 香港中文大學出版社. 1978.

7. (至)郭軖注. 山海經, 載於《文淵閣四庫全書》第 一○四二冊《子部三四八.小說家類》。臺灣商務 印書館. 1983-1986.

8. (唐)韓愈. 韓昌黎集. 河洛圖書出版社. 1975.

9. (唐)王冰次注, (宋)林億等校正. 黃帝內經素問(附釋 文), 載於《文淵閣四庫全書》第七三三冊《子部三 九·醫家類》. 臺灣商務印書館. 1983-1986.

10.（唐)王冰注，(宋)史崧校正音釋。靈樞經, 載於 《文淵閣四庫全書》第七三三冊《子部三九·醫 家類》. 臺灣商務印書館. 1983-1986.

11. (唐)歐陽詢撰, 汪紹楹校. 藝文類聚(附索引) (上、下冊)。上海古籍出版社. 1965.

12. (宋)朱喜. 論語集註大全. 保景文化社. 1986.

13. (宋)李昉等撰. 太平御覽(全四冊), 中華書局. 1960.

14. (清)阮元校刻. 十三經注疏(附校勘記)(全二冊). 中華書局. 1980.

15. (淸)孫詒讓撰, 棌啟治點校. 墨子閒詁(上、下 冊)。中華書局. 2001.

16. (清)孫詒讓著, 許嘉珞主編, 雪克點校. 大戴禮 記侢補(外四種). 中華書局. 2010.

17. (淸)段玉裁注. 說文解字注. 藝文印書館. 1994.

18. 上海古籍出版社編. 四部精要·子部. 上海古籍
出版社. 1982.

19.上海書店編.二十十五史(全十二冊)。上海古籍出 版社. 1986.

〈中文參考資料〉

1. 王利器. 呂氏春秋注疏(全四冊). 巴蜀書社. 2002.

2. 牟鍾鑒，張踐合著．中國宗教通史(上、下冊)，社 會科學文獻出版社. 2000.

3. 朱天順. 中國古代宗教初探. 上海人民出版社. 1982.

4. 宋鎮豪．夏商社會生活史(上、下)(增訂本)。中國 社會科學出版社. 2005.

5. 宋兆麟. 巫與巫術. 四川民族出版社. 1989.

6. 李學勤. 文物中的古文明. 商務印書館. 2008.

7. 李學勤主編. 淸華大學藏戰國竹簡(壹)(上、下 冊). 中西書局. 2010.

8. 吳則虞編. 晏子春秋集釋(全二両). 中華書局. 1962.

9. 周策縱. 古巫醫與“六詩”考 -- 中國浪漫文學探 源. 聯經出版公司. 1986.

10. 胡新生. 中國古代巫術. 山東人民出版社. 1999.

11. 馬承源主編. 海博物館藏戰國楚竹書(一)-(八). 上海古籍出版社. 2001-2011.

12. 馬伯英. 中國醫學文化史. 上海人民出版社. 1994.

13. 袁珂校注. 山海經校注. 上海古籍出版社. 1980.

14. 徐富昌. 睡虎地秦簡㸴究. 文史哲出版社. 1993.

15. 梁啟雄. 韓子淺解(上、下冊). 中華書局. 1960.

16. 梁釗轁. 中國古代巫術 -- 宗敎起源和發展. 中山大學出版社. 1989.

17. 許進雄. 中國古代社會 -- 文字與人類學的透 視(修訂本). 臺灣商務印書館. 1995.

18. 陳邦賢. 中國醫學史. 商務印書館. 1954.

19. 黃懷信, 張禁鎔, 田旭東撰. 逸周書录校集注(修 訂本)(上、下冊)。上海古籍出版社. 2007.

20. 黃暉撰. 論衡校釋(附劉昐遂集解)(全四冊)。中 華書局. 1990.

21. 楊伯峻. 論語譯注. 中華書局. 1958.

22. 詹鄞金金. 心智的誤區 -- 巫術與中國巫術文化. 上海敉育出版社. 2001.

23．趙容俊．殷商甲骨卜辭所見之巫術。文津出版 
社. 2003.

24. 趙容俊. 殷商甲骨卜辭所見之巫術(增訂本)。中 華書局. 2011.

25. 漢語大詞典編輯委員會編. 漢語大詞典(正文十 二卷，附錄、索引一卷)。漢語大詞典出版社. 1991-1994.

26. 銀雀山漢墓竹簡整理小組編. 銀雀山漢墓竹簡 (辜). 文物出版社. 1985.

27. 黎翔鳳撰, 梁運華整理. 管子校注(全三冊). 中 華書局. 2004.

28. 鄧啟耀. 中國巫盛考察. 上海文藝出版社. 1999.

29. 嚴一萍撰. 殷栔徴毉. 藝文印書館. 1991.

〈論文及其他〉

1. 林志鵬. 殷代巫梘活動䂰究. 臺灣大學中文所碩 土論文. 2003.

2. 陳儎柣. 左傳中巫術之研究. 政治大學中文所博 土論文. 1989 .

3. 趙容俊. 先秦巫者的醫療活動㸴究. 清華大學歷 史系博士論文. 2010 .

4. 趙容俊. 早期中國醫學與陰陽五行思想考察. 民 族文化論叢. 2012(52).

5. 趙容俊. 兩周時期中國醫學的專業化小考. 大韓 韓醫學原典學會誌. 2013(26-1).

6. 謝康. 中國古代巫術文化及其社會功能(上、下). 中華文化復興月刊. 1976(1)-(2).

\section{〈外國地區的參考資料〉}

1. 山田慶兒著, 廖育群, 李建民編譯. 中國古代醫學 的形成. 東大圖書公司. 2003.

2. Walter Hutchinson(沃爾特哈欽森). Customs of the World, Vol. I -- a popular account of the manners, rites and ceremonies of men and women in all countries: 世界風俗. Neeraj Publishing House. 1984. 